\title{
TRADISI ILMIAH DALAM PENDIDIKAN PESANTREN
}

\author{
Ainul Yaqin ${ }^{1}$ dan Nanda Septiana ${ }^{2}$ \\ ${ }^{1}$ Sekolah Tinggi Ilmu Administrasi Bayuangga \\ ${ }^{2}$ IAIN Madura
}

\begin{abstract}
This study describes the education that developed in Islamic boarding schools. The focus of the discussion is the existence and traditions that exist in the pesantren. The writing method used to obtain data is the library method. The conclusions obtained in this paper are Islamic boarding schools are a real form of educational manifestations that are able to form a strong personality for each of their students. Islamic boarding schools are an original form of archipelago education created with Islamic tradition values that have their own uniqueness in building civilization. The form of scientific tradition that was built in pesantren in the form of education in the form of munadharah, a pattern of education maintained and maintained with its classical form in pesantren, collecting books and classical manuscripts to establish libraries containing various sciences and integrated in santri as human beings who love science. With the tradition that is owned, Islamic boarding schools are able to build the character of the santri to become human beings who are able to maintain scientific traditions that have long been built by 'ulama' for the sake of science and future sustainability.
\end{abstract}

Keywords: Education; Scientific tradition; Islamic boarding school

\section{Pendahuluan}

Islam pernah mengalami masa keemasan pada masanya (golden age). Pada masa tersebut Islam banyak menguggguli bidang keilmuan, tidak hanya berupa ilmu agama, namun ilmu pengetahuan umum, peradaban dan kebudayaan yang hingga saat ini dapat kita rasakan dan jumpai dalam berbagai bentuk. Informasi tersebut dapat kita lihat dalam berbagai literatur sejarah, bangunan-bangunan yang bercorak Islam seperti istana sultan, rumah, perguruan tinggi, kesenian serta institusi dalam berbagai bidang keilmuan sosial, politik, pendidikan ekonomi dan sebagainya. Keadaan yang demikian, karena dalam Islam terdapat tradisi ilmiah yang terus berkembang tanpa meninggalkan esensi keberadaan Islam itu sendiri, sehingga atmosfer ini terus berkembang dengan sangat kuat dan efektif (Nata, 2010: 234). Tradisi ini selanjutnya menjadi ciri khas budaya dan kebiasaan yang tumbuh serta dapat 
dirasakan dalam proses pendidikan Islam. Kemudian dalam perkembangannya, pendidikan Islam mengalam penyesuaian dengan lokalitas di Indonesia. Secara tradisonal pendidikan Islam di Indonesia disebut dengan pesantren.

Pesantren pada mulanya merupakan sebuah institusi yang memfokuskan pada pendidikan dan penyiaran agama Islam di tanah Jawa. Keberadaanya dalam masyarakat mempunyai peran fungsional dalam pendidikan dan penyebaran Islam dengan sistem pembelajaran yang berbeda dengan lembaga pendidikan Islam lain di dunia. Dewasa ini keberadaan pesantren sangat krusial, karena kewajibannya tidak hanya mentransformasikan pengetahuan (khowledge) tetapi juga dituntut untuk mengintegrasikan niai-nilai (value) pada peserta didik. Bentuk nilai yang di internalisasikan paling tidak meliputi: nilai etika (akhlak), estetika sosial, ekonimis, politik, pengetahuan umum, serta pengetahuan mengenai ilahiyah.

Terlaksananya internalisasi nilai dan tranformasi pengetahuan pada peserta didik di pesantren merupakan tugas berat di tengah kehidupan masyarakat yang kompleks pada era globalisasi yang begitu pesat dengan kemajuan teknologi yang serba modern. Dengan mengetahui keberadaan pesantren di atas dapat dipahami bahwa sebagai lembaga pendidikan yang berjumlah besar pesantren mempunyai saham dalam pola pembentukan manusia yang bersikap religius. Lembaga ini telah banyak memberikan banyak pemimpin bangsa di masa lalu, dan juga pasti di masa yang datang akan banyak memberikan sumbangsih pemimpin dimasa yang akan datang.

Ahmad Tafsir (2010: 203) menuliskan Peran pesantren di masa sekarang sangat jelas. Contoh yang dapat kita cermati terutama dalam tahun ini, yang merupakan tahun politik banyak kalangan pemimpin politik mendekati pesantren terutama ketika mendekali pemilu, mereka pasti berbondongbondong dan silih berganti untuk sowan (mendatangi kiai/pimpinan pesantren) guna mendapatkan empati dan dukungan. Hal ini dirasa tepat karena mereka bersinggungan langsung dengan pemimpin pesantren yang sekaligus menjadi pemimpin rohani bagi masyarakat sekitarnya. Peran ini juga berdampak pada masa-masa mendatang, karena kita ketahuui banyak kalangan pimpinan elit 
yang dari jebolan universitas ternama namun tidak memiliki nilai-nilai yang dibanggakan sebagai pemimpin. Disinilah peran pesantren sebagai lembaga pendidikan masa kini menjad harapan masyarakat masa depan karena keistiqomahannya dalam melaksanakan tradisi di pesantren dibawa pulang dan mengambil peran di masyarakat kelak.

Kebeeradaan ini dapat kita pahami sejak awal hingga kini, pendidikan Islam di Indonesia khususnya pesantren banyak mengalami perkembagan namun masih dengan substansi dan tradisi ilmiah yang tidak hilang luntur dengan perkembangan pendidikan yang terjadi. Meskipun banyak kelemahan yang dimiliki oleh pesantren, sebagian besar diantaranya masih tetap medapatkan tempat bagi masyarakat Indonesia untuk mempercayakan pendidikannya kepada pesantren. Terlebih pesantren memiliki figur dan tradisi yang tidak hilang sehingga mampu menjaga kualitas keilmuannya, terfokus pada perkembangan keilmuan peserta didiknya dan mampu membangun komunikasi yang baik dengan komunitas sosial dan pemerintah.

\section{Eksistensi Pesantren}

Pada umumnya berdirinya suatu pesantren diawali dari pengakuan masyarakat tentang keunggulan dan ketinggian ilmu seorang guru atau kiai. Karena keinginan menuntut ilmu dari guru tersebut maka masyarakat sekitar bahkan dari luar daerah berdatangan. Mereka lalu membangun tempat tinggal yang sederhana yang disebut pondok yang berarti rumah yang terbuat dari bambu. Di samping itu kata pondok mungkin juga berasal dari bahasa Arab "Funduq" yang berarti hotel atau asrama. Pesantren yang dalam pandangan Hadratusysyekh KH. Hasani Nawawie (Ahmad, 2009: 184-185). merupakan sebuah lembaga yang sama hal nya dengan sebuah masjid, yang mana dalam tujuan dibangunkan sebuah masjid adalah agar setiap muslim yang ada didaerah tersebut bertambah keimanan dan ketaqwaannya, sehingga dalam permasalahan ini beliau mendefinisikan pesantren sebagai lembaga yang berfungsi untuk membentuk para santrinya agar bertaqwa kepada Allah SWT, sehingga masyarakat yang ada disekitarnya dan para santri khususnya 
mempunyai kesempatan untuk belajar dan bertaqwa kepada Allah SWT. Definisi yang diberikan oleh Hadratusysyekh $\mathrm{KH}$. Hasani Nawawie bukannya tanpa landasan, hal ini sebagai mana terdapat dalam al Qur'an (Q.S. at Taubah: 108);

Artinya: "... Sesungguh-Nya masjid yang didirikan atas dasar taqwa (masjid Quba), sejak hari pertama adalah lebih patut kamu sholat didalamnya. didalamnya masjid itu ada orang-orang yang ingin membersihkan diri. dan Sesungguhnya Allah menyukai orang-orang yang bersih".

Pesantren yang diakui sebagai model pendidikan awal Islam di Indonesia sampai saaat ini masih eksis dan mampu mempertahankan kredibilitasnya di masyakarat untuk mencetak santri yang mampu memiliki nilai religious dan taqwa yang sangat tinggi. Selain bertujuan untuk menjadikan santrinya mempunyai nilai religious dan bertaqwa, pesantren mengambil peran sebagai lembaga pendidikan, bimbingan keilmuan umum, pelatihan, pengembangan masyarakat dan sekaligus menjadi simbol dari sebuah budaya (Nafi', 2007:11). Sehingga dalam hal ini pesantren sangatlah kompleks keberadaanya dalam masyarakat.

Dalam pesantren ada beberapa hal yang harus dipenuhi sehingga menjadi karakter dan ciri khas tersendiri yang dimiliki. Ciri khas yang termasuk didalamnya ialah proses pendidikan beserta tradisi ilmiah yang ada dalam sebuah lembaga pesantren. Dalam kaitannya hal ini (Yasmadi, 2002:62), tradisi lembaga pondok pesantren sudah ada mulai berabad-abad lamanya. Secara histroris pondok pesantren bukan hanya mengandung makna keIslaman, tetapi juga makna keaslian Indonesia. Sebab, memang cikal bakal lembaga pondok pesantren sebenarnya sudah ada pada masa hindu, budha dan Islam hanya tinggal meneruskan, melestarikan, dan mengIslamkannya sehingga membentuk simbol-simbol Islam dalam pesantren.

Simbol kebudayaan yang melekat dalam pesantren tidak lepas dari keberadaan awal pesantren yang digunakan oleh orang-orang hindu-budha pada zaman dulu dan keberadaannya telah ada jauh sebelum Islam masuk di Indonesia. Sehingga dapat disimpulkan bahwa pesantren bukanlah dari tradisi 
Islam, melainkan tradisi lokal masyarakat Indonesia. Pesantren dalam buku Praksis Pembelajaran Pesantren dijelaskan bahwa kelahirannya berasal dari dua keinginan yang bertemu, keinginan orang yang ingin mencari ilmu (santri) dan keinginan orang yang secara ikhlas mengajarkan ilmu dan pengalamannya kepada sesama (kiai). Sehingga didalam pesantren pasti terdapat dua simbol tersebut. Tidak hanya berhenti dalam hal tersebut (Ibrahim, 2016: 90-93) mengungkapkan pesantren juga sebagai lembaga pendidikan yang mengajarkan, mengembangkan dan menyebarkan ilmu agama Islam, melainkan juga lembaga kemasyarakatan yang memiliki pranata sendiri yang memiliki fungsi amal terhadap masyarakat serta hubungan tata nilai dengan kultur masyarakat, khususnya yang ada dalam lingkungannya.

\section{Karakteristik Pondok Pesantren}

Dalam ponpes ada beberapa hal yang harus dipenuhi didalamnya, sehingga menjadi karakter tersendiri termasuk didalamnya ialah proses pembelajaran. Dalam menanggapi pendidikan Islam di Indonesia maka tidak jauh dengan adanya lembaga ponpes. Dalam kaitannya hal ini, strategi lembaga ponpes sudah ada mulai ber abad-abad lamanya. Secara histroris ponpes bukan hanya mengandung makna keIslaman, tetapi juga makna keaslian Indonesia. Sebab, cikal bakal lembaga ponpes sebenarnya sudah ada pada masa Hindu-Budha, dan Islam hanya tinggal meneruskan, melestarikan, dan mengIslamkannya.

Berdasarkan pada elemen yang dimiliki, Ziemik memetakan bahwa pesantren pada akhir abad $20 \mathrm{M}$ dapat dibedakan menjadi lima tipologi;

Pola pertama, Pesantren yang terdiri dari masjid dan rumah kiai. Pondok pesantren seperti ini masih bersifat sederhana, dimana kiai mempergunakan masjid atau rumahnya sendiri untuk tempat mengajar. Dalam hal ini santri yang ada hanya dari daerah sekitar sendiri. Pesantren seperti ini khas dari pesantren sufi (tarekat) yang memberikan pengajaran bagi anggota terekat. Pesantren seperti ini tidak memiliki pondokan sebagai asrama sehingga para santri tinggal bersama di rumah kiai. 
Pesantren seperti ini merupakan pesantren yang paling sederhana yang hanya mengajarkan kitab klasik.

Pola kedua, Pesantren yang terdiri masjd, rumah kiai dan pondok penginapan bagi para santri yang datang dari daerah-daerah yang jauh. Pola pesantren yang kedua sudah dilengkapi dengan pondokan bagi para santri yang datang untuk mencari ilmu dan belajar. Pesantren pada pola kedua ini telah memiliki semua komponen yangn dimiliki pesantren klasik, seperti masjid dan tempat belajar yang terpisah dengan dari pondokan.

Pola ketiga, pola Pesantren yang ketiga telah terdiri dari masjid, rumah kiai dan pondok dengan pembelajaran sistem sorogan dan wetonan, pesantren dengan tipe yang ketiga ini telah menyelenggarakan pendidikan formal seperti madrasah diniyah dan msadrasah yang memberikan pelajaran umum dan berorientasi pada pelajaran-pelajaran umum.

Pola keempat, pada pola yang keempat Pesantren sudah mulai berkembang dari pada pola yang ketiga, dalam pola keempat pesantren mulai mengembangkan ketrampilan-ketrampilan yang dimilki oleh setiap santri. Selain itu pesantren pada tipe ini menyediakan tempat untuk mengasah ketrampilan yang dimiliki, mulai dari koprasi, kerajinan, lading sawah dan lain sebaginya yangn mendukung ketrampilan yang dimiliki.

Pola kelima, pola Pesantren yangn terakhir merupakan pesantren yang telah berkembang dan bisa disebut dengan pesantren modern. Di samping memiliki rumah kiai, ustadz, pondok, madrasah dan sekolah umum. Terdapat pula bangunan lain seperti perpustakaan, dapur umum, ruang makan, kantor administrasi, took, ruang penginapan bagi wali santri dan lain sebagainya. Pada jenis yang kelima ini pesantren yang memiliki pola pesantren klasik yang dilengkapi dengan sekolah formal mulai dari tingkat SD sampai dengan tingkat universitas. Sama dengan pola yang keempat, pesantren pola kelima juga mengembangkan daya kreativitas dan ketrampilan yang dimiliki oleh setiap santri. 
Secara tipologi pesantren di Jawa Timur dapat digolongkan menjadi dua kelompok besar yaitu:

Pertama: Pesantren Salafi, yaitu pesantren yang tetap mempertahankan sistem (materi pengajaran) yang sumbernya kitab-kitab klasik Islam atau kitab dengan huruf Arab gundul (tanpa baris apapun). Sistem sorogan (individual) menjadi sendi utama yang diterapkan. Pengetahuan non agama tidak diajarkan.

Kedua: Pesantren Khalafi, yaitu sistem pesantren yang menerapkan sistem madrasah yaitu pengajaran secara klasikal, dan memasukan pengetahuan umum dan bahasa non-arab dalam kurikulum. Dan pada akhir-akhir ini menambahnya berbagai ketermpilan.

\section{Tradisi Ilmiah di Pesantren}

Tradisi berasal dari bahasa inggris tradition yang berarti sebuah kebiasaan. Dalam bahasa lain, tradisi diartikan sebagai sebuah bentuk budaya yang ada di dalam masyarakat. Sehingga dalam hal ini tradisi yang dimaksud merupakan aspek kebudayaan yang tidak hanya diterapkan begitu saja, namun berupa penanaman nilai, cara berfikir yang dikembangkan dalam sebuah kehidupan. Sari Rudiyati dalam sebuah buku, budaya diartikan sebagai "...the constellation of value, belief as institution unique to given group of people" dapat dipahami sebagai kumpulan nilai, kepercayaan sebagai adat kebiasaan yang dimiliki oleh sekelompok orang. Karkono Kamajaya Partokusumo (1999: 210) memberikan pengertian lain dalam buku yang ditulisnya budaya memiliki arti sebagai berikut:

Pertama, Ki Hadjar Dewantara menerangkan bahwa Budaya berasal dari perkataan Budi yang dengan singkat diartikan sebagai jiwa yang telah masak. Budaya atau kebudayaan adalah buah budi manusia yang berasal dari perkataan Cultura, asal bahasa Latin Colere yang berarti memelihara, memajukan dan memuja-muja. Dari sifat kodrati ke sifat kebudayaan, dari natur menjadi culture. Arti kata budi pada pokoknya terdiri dari tiga kekuatan jiwa manusia, yakni; 1. Pikiran; 2. Rasa; 3. Kemauan (cipata, 
rasa dan karsa). Dengan samanya arti antaran tradisi dan Kebudayaan dapat dipahamai bahwa tradisi juga merupakan keinginan dan hasrat manusia untuk mencapai hidup yang serba senang, hidup lahir dan batin. Dengan perkataan lain tradisi merupakan hasil perjuangan manusia dalam melawan segala kekuatan alam dan pengaruh-pengaruh jaman yang dirintangi kemajuannya, kemajuan kearah hidup selamat dan bahagia.

Kedua, Sutan Takdir Alisyahbana mempunyai definisi budaya sebagai pola kejiwaaan yang ada di dalamnya terkandung dorongan-dorongan hidup dasar, insting, perasaan, dengan pikiran, kemauan dan fantasi yang kita namakan budi. Budi itu merupakan dasar segala kehidupan kebudayaan manusia.

Dengan adanya beberapa pengertian di atas dapat dipahami bahwa makna tradisi merupakan sebuah aspek kebudayan yang memelihara faham tradisonal. Tradisi yang ingin dibangun merupakan tradisi ilmiah yang dibawa Islam dalam dunia pesantren sehingga membentuk kehidupan yang unik dan mampu membangun peradaban Islam maju hingga sekarang.

Tradisi ilmiah sendiri telah ada sebelum Islam datang, tradisi ini berkembang di berbagai negara seperti Yunani, Cina, Persia dan lainnya. Ketika Islam mulai berkembang bagian Negara ini mengalami kemunduran dalam memelihara tradisi ilmiah, sebagai akibat adanya konfllik dalam politik, ekonomi dan lain sebaginya. Sehingga banyak filsuf Yunani yang mulai meninggalkan kampung halamannya untuk mengembara untuk mengembangkan ilmu pengetahuan yang mereka miliki ke negara tetangga, seperti Mesir, Alexandria dan Persia. Disinilah mereka mulai mengembangkan dan melanjutkan kembali tradisi ilmiah yang mereka lakukan sebelumnya.

Abudin Nata (2010: 235) Sampainya tradisi ilmiah di Indonesia yang di bawa oleh para penyebar Islam bersumber dari dua golongan. Golontgan pertama yakni golongan ilmu pengetahuan yang datang dari abad ke 13 masehi, bersama dengan masuknya Islam dengan lingkup yang luas, dan golongan kedua, ketika para pemikir Islam di tanah nusantara menggali ilmu pengetahuan di semenanjung arab, dan kembali ke Indonesia dengan 
membawa ilmu serta tradisi ilmiah yang didapat selama mengembangkan ilmunya. Dengan ilmu pengetahuan serta tradisi yang dikembangkan oleh umat Islam di tanah jawa menjadikan Islam sebagai pusat perhatian dan mendominasi di Indonesia. Dua golongan inilah yang kemudian membentuk pola pendidikan di pesantren yang kemudian menghadirkan para ulma' yang mempunyai jiwa yang tangguh dalam mempelajari ilmu pengetahuan dan agama. Banyak tokoh ulama yang lahir dari pesantren misalnya Ky. Nawawi Banten, Ky. Khalil Bangkalan, Ky. Mahfudz Tremas, Ky. Hasyim Asy'ary Jombang dan banyak para ulama' hingga sekarang yang tidak terlepas kelimuannya sampai sekarang. Para ulama' ini membawa orientasi yang sangat berpengaruh bagi Islam dimasa mendatang serta guna mewarnai orientasi keilmuan di lingkungan pesantren.

Dalam praktinya pesantren merupakan lembaga pendidikan Islam yang mampu berkembang dan menjaga tradisi ilmiah, dalam kagiatan dan program yang tumbuh baik dalam lingkungan maupun dalam keseharian santri yang mengarahkan para santri untuk mengemangkan potensinya secara optimal untuk menjadi orang yang berkademis yang mampu mendalami ilmu fiqih dan pengetahuan lainnya secara tuntas. Tradisi ilmiah yang berkembang dalam dunia pesantren ialah:

\section{Munadharah}

Munadharah yang dimaksud dalam kajian ini merupakan bentuk debat yang menjadi bentuk tradisi islam dalam pesantren. Menurut Abudin Nata (2010: 244) Kegiatan ini dilakukan untuk saling bertukar pikiran dan pemahaman sesama santri, menguji pemahaman serta wawasan yang dikuasai para santri sehingga tradisi ini mampu mengembangkan pola pikir ilmiah yang dimiliki dari setiap santri secara bersama-sama. Dengan adanya munadharah para santri mampu mengembangkan pendapat dan pemikirannya bersama, sehingga pendapat yang ada dianggap milik bersama yang bisa dikritik, saling adu argumen, dibantah serta disempurnakan untuk mendapatkan gagasan yang diterima secara bersama-sama. 
Tradisi ini berkembang dengan berbagai nama, namun perbedaan nama yang ada tidak menghilangkan esensi dalam kegiatan tersebut. Melalui kegiatan tersebut ilmu pengetahuan mampu berkembang dan memiliki tingkat validasi yang tinggi. Hal ini bisa dilihat dalam proses munadharah yang mana dalam proses tersebut selalu di awasi oleh seorang senior yang didasari dengan rasa "andap asor" (masih miskin ilmu), take and give (saling bertukar pikiran antar santri), saling toleransi demi mendaptkan hakihat ilmu yang dimiliki. Dengan demikian kegiatan ini tidak mengarahkan pada perpecahan atau sebagainya.

\section{Pola Pendidikan Pesantren}

Adanya muatan pendidikan formal kemudian masuknya pengajaran pengetahuan umum serta modernism dalam pengelolaan pesantren sebagai bentuk kemajuan dalam pendidikan Islam tidak kemudian melunturkan pola pendidikan klasik yang telah lama diterapkan oleh para ulama' terdahulu. Menurut Moh Roqib (2009: 161) Pola pendidikan Islam klasik tersebut berupa pengajaran kitab-kitab klasik, al Quran dan lain sebagainya, pengajaran ini sebagai bentuk apresiasi serta bahan pembelajaran tradisioanal yang dijaga dalam pendidikan Islam sebagai upaya untuk meneruskan tujuan utama pesantren dalam mendidik dan mencetak ulama yang benar-benar faham akan Islam, kebutuhan masyarakat dan pengetahuan yang bersumber dari kitab klasik yang berbahsa arab yang disusun oleh para ulama' yang tergolong mutaakhir yang telah dipercaya kevalidan sehingga dijadikan salah satu unsur yang paling penting dalam proses pembelajaran di pesantren

Dalam sebuah pesantren dalam proses pembelajarannya dapat dipelajari ada beberapa model yang menjadi ciri khas didalamnya, diantaranya:

Pertama; Model sorogan. Santri secara individu atau secara kelompok datang menghadap kiai atau ustadzah dengan membawa kitab tertentu. Pada sistem ini santri bersikap aktif membawa secara individu, memberi makna dan menjelaskan. Sedangkan guru menyimak dengan memberi teguran, bimbingan dan sesekali memberikan keterangan tambahan. 
Kedua; Model weton, kiai membaca dan menjelaskan, peserta menyimak dan memberi makna dan jarang sekali terjadi dialog. Kelebihan sistem ini peserta tidak terbatas pada jumlah, usia dan kemampuan. Pengajian kilatan bulan Ramadhan yang diselenggarakan sangat efektif menggunakan sistem ini.

Ketiga; Model majelis ta'lim adalah media penyampaian ajaran Islam yang bersifat umum dan terbuka. Para jama'ah terdiri dari berbagai lapisan yang memiliki latar belakang pengetahuan bermacam-macam dan tidak dibatasi oleh tingkatan usia maupun perbedaan kelamin. Pengajian semacam ini hanya diadakan pada waktu-waktu tertentu saja

Keempat; Model bahshul masa'il, model ini lebih mirip pada diskusi atau seminar beberapa santri dengan jumlah tertentu membentuk halaqah yang dipimpin langsung oleh kiai atau ustadznya, atau mungkin juga oleh santri senior, untuk membahas atau mengkaji suatu persoalan yang telah ditentukan sebelumnya.

\section{Mengoleksi Manuskrip Kitab-Kita Klasik}

Berkembangnya ilmu pengetahuan pada masa lalu membawa Islam pada masa kejayaan yang luar biasa dan telah menorehkan banyak pemikir Islam dalam berbagai aspek ilmu, baik dalam ilmu agama maupun ilmu pengetahuan lainnya. Demi membangun keberlangsungan estafet pengetahuan tersebut para pemikir Islam dan para ulama' terdahulu mengebadikannya dalam bentuk karya ilmiah, berupa kitab-kitab dan manuskrip. Manuskrip dan kitab-kitab yang ditulis berisi mengenai berbagai gagasan, konsep serta teori yang dipahami secara mendetail oleh para ulama' dan sangat penting keberadaanya bagi keberlangsunan penerus di masa mendatang. Hal ini mendorong para santri yang belajar di pesantren untuk mengoleksi dan mempelajari dari setiap buku dan manuskrip yang tulis oleh para ulama' terdahulu guna mendapatkan berbagai ilmu yang ingin didalami. Dengan demikian para santri berusaha mengumpulkan manuskrip dan buku bahkan tidak sedikit yang menghimpunnya 
dalam sebuah perpustakaan. Sehubungan dengan tradisi tersebut banyak pesantren yang melengkapi keberadaanya dengan sebuah perpustakaan.

\section{Mencintai Ilmu Pengetahuan}

Santri yang menempuh pendidikan di pesantren banyak mendapatkan pelajaran, baik untuk perkembangan ilmu pengetahuan maupun perkembangan individu dari setiap santri. Dengan demikian para santri sudah pasti sangat menghormati dan mencintai ilmu pengetahuan termotivasi untuk mengabdikan jiwa, raga, tenaga dan pikirannya untuk kemajuan ilmu pengetahuan. Para santri yang ada di pesantren tidak tertarik untuk melakukan kegiatan yang tidak ada hubungannya dengan perkembangan ilmu, bahkan hampir 24 jam kehidupan di pesantren bersentuhan dengan ilmu. Demikian ini dapat dilihat dari kemauan yang kuat dari setiap santri yang datang dan menguatkan diri datang dari berbagai daerah untuk mencari dan menetap di pesantren bahkan meninggalkan keluarga demi mendapatkan ilmu pengetahuan yang dicintai.

Kehidupan para santri di pesantren menjadikan mereka mencintai ilmu, bahkan sebagian dari pada santri mengabdikan hidupnya untuk menerjemahkan manuskrip dan buku asing kedalam bahasa mereka, menyalin serta melakukan kegiatan menulis bahkan meneliti demi mengabadikan ilmu yang mereka peroleh dan kemudian menyebarkan pengetahuan tersebut keberbagai pelosok yang mampu mereka jamah. Kegiatan ini merupakan bentuk kecintaan mereka terhadap ilmu yang diperoleh di pesantren. Para santri menganggap mencintai dan menuntut ilmu merupakan salah satu bentuk ibadah, jihad dijalan Allah SWT. Keyakinan ini tumbuh dari pemahaman bahwa setiap orang yang mencurahkan kehidupannya pada ilmu pengetahuan pasti ditinggikan derajatnya, mereka itulah para pencinta ilmu seperti para guru, ustad dan kiai yang ada di pesantren yang kemudian menjadi tauladan dalam kehidupan santri sehari-hari. Dari kecintaan inilah kemudian para santri mampu memahai makna kehidupan, keberadaan manusia, peranan dan tanggung jawab dalam kehidupan di masyarakat kelak. 


\section{Penutup}

Eksistensi pesantren dimulai sejak awal berdirinya pesantren itu sendiri, keberadaan sebuah pesantren diawali oleh pengakuan masyarakat sekitar terhadap tokoh atau ulama' yang ada di sekitar lingkungan mereka. Dengan datangnya kepercayaan dari masyarakat sekitar, banyak santri yang berdatangan untuk memperdalam ilmu memperdalam keimanan dan ketaqwaan seseorang. Dalam kaitannya pesantren merupakan sebuah lembaga pendidikan Islam yang merupakan bentuk asli pendidikan nusantara yang terlahir dari kebudayaan hindu buda yang kemudian berafiliasi dengan tradisi kebudayaan islam. Namun hal ini tidak melunturkan tujuan awalnya yakni membangun peradaban islam yang bertaqwa kepada Allah SWT. Hal inilah yang kemudian menjadi sumbu penyemangat untuk menjaga tradisi yang ada di dalam pesantren hingga hari ini.

Tradisi ilmiah yang ada dalam pesantren merupakan sebuah bentuk interpretasi dari sebuah budaya yang tercipta dalam sebuah pesantren yang terus berjalan dan dijaga hingga sekarang. Bentuk tradisi ilmiah yang ada dalam sebuah pesantren ialah. Pertama, Munadharah tradisi ini berbentuk tradisi debat yang dilakukan untuk saling bertukar pikiran dan pemahaman sesama santri, menguji pemahaman serta wawasan yang dikuasai serta mengembangkan pola pikir yang dimiliki para santri sehingga mereka mampu mendapatkan gagasan yang dapat diterima secara bersama-sama. Kedua, Pola Pendidikan di Pesantren. Dalam sebuah pesantren baik secara modern maupun salaf tidak meninggalkan model pendidikan yang telah lama dilakukan secara turun temurun dilakukan, diantaranya yakni model sorogan dimana para santri membacakan kitab yang dipunya kemudian sang kiyai atau ustadz memberikan kesimpulan dan memberikan masukan atas keterangan santrinya. Model kedua yakni weton, model ini para santri lebih bersifat pasif karena dalam model ini lebih banyak kiyai atau ustad yang memberikan penjelasan dan pemaknaan terhadap kitab yang dikaji, namun kegiatan ini bisa bersifat efisien ketika jumlah yang mengaji banyak. Model ketiga Majlis Taklim proses ini merupakan 
bentuk kegiatan yang bersifat umum dan terbuka untuk berbagai kalangan. Ketiga, Mengoleksi Manuskrip dan Kitab-kitab klasik, hal ini termasuk tradisi ilmiah yang dilakukan dalam pesantren karena dalam perjalanannya banyak para ulama' menuangkan pikiran dan gagasan dalam sebuah manuskrip dan kitab-kitab klasik, oleh karenanya demi memahami dan mendalami ilmu pengetahuan yang dikuasai ulma' tersebut para santri rela untuk membeli dan mengoleksi berbagai manuskrip yang ditulisnya bahkan tidak sedikit para santri membangun perpustakaannya sendiri demi menjaga manuskrip dan kitab klasik yang dimiliki. Keempat, Mencinttai Ilmu Pengetahuan. Kehidupan dalam pesantren menjadikan kehidupan para santri mencintai ilmu pengetahuan hal ini terjadi karena hampir 24 jam kehidupan para santri selalu ditemani dengan perkembangan ilmu. Kegiatan ini menjadikan para santri mencintai ilmu, bahkan tak sedikit para santri yang mengabdikan hidupnya demi ilmu pengetahuan, baik berupa menerjemahkan manuskrip kedalan bahasa yang dipahamai, melakukan penelitian bahkan menulis setiap gagasan yang dimiliki sampai menjadi sebuah buku. Hal ini merupakan bukti nyata yang dimiliki para santri atas kecintaan ilmu pengetahuan. 


\section{DAFTAR PUSTAKA}

Ahmad, Moch. Achyat. 2009. Mengapa Saya Harus Mondok di Pesantren. Pasuruan: Pustaka Sidogiri.

Anwar, Ali. 2011. Pembaharuan Pendidikan Di Pesantren Lirboyo Kediri. Yogyakarta: Pustaka Pelajar.

Departemen Agama RI Direktorat Jendral Kelembagaan Agama Islam. 2003. Pondok Pesantren dan Madrasah Diniyah pertumbuhan dan perkembangannya. Jakarta: Departemen Agama RI.

Irham. 2016. Pesantren Manhaj Salafi: pendidikan Islam model baru di Indoenesia. Ulul Albab Vol. 17, No. 1.

Nafi', M. Dian,. dkk. 2007. Praksis Pembelajaran Pesantren. Yogyakarta: Intitute for Training and Development.

Nata, Abudin. 2010. IImu Pendidikan Islam. Jakarta: Kencana.

Partokusumo, H. Karkono Kamajaya. 1999. Kebudayaan Jawa dan proses Demokratisasi. Judul utama; Pembebasan Budaya Budaya Kita. editor; Agus R. Sarjono. Jakarta: PT. Gramedia Pustaka Utama.

Pondok Pesantren Tebuireng. 2014. Buku Panduan Satri Pesantren Tebuireng. Jombang: Pengurus Pondok Pesantren Tebuireng.

Roqib, Moh. 2009. IImu Pendidikan Islam Pengembangan Pendidikan Integratif di Sekolah, Keluarga dan Masyarakat. Yogyakarta: LKiS Yogyakarta.

Rudiyati, Sari. Pendidikan Populis Berwawasan Budaya (Membangun Budaya Sekolah Inklusif Bagi Anak Berkebutuhan Pendidikan Khusus Menuju Pendidikan Populis). Yogyakarta: Fakultas IImu Pendidikan Universitas Negeri Yogyakarta.

Tafsir, Ahmad. 2010. Ilmu Pendidikan Dalam Perspektif Islam. Bandung: Remaja Rosdakarya.

Yasmadi. 2002. Modernisasi Pesantren Kritik Nurcholis Madjid Terhadap Pendidikan Islam Tradisional. Jakarta: ciputat Press. 